\title{
Dad Rudd, M.P. and the making of a national audience.
}

Dad Rudd, M.P. was the fourth and final film made by Ken G. Hall based on characters originally created by 'Steele Rudd' (Arthur Hoey Davis) in 1895. It. was also the first of four films to receive a $£ 15,000$ overdraft from the NSW government as part of an attempt to encourage local film production. It was released by Cinesound in Australia in June 1940. According to the Australasian's film critic 'The Chiel,' when the film was shown in Melbourne, 'a queue that was 100 yards long to the box office, a crowded theatre, and sustained applause indicated that the Australian people have no fault to find with "Dad Rudd, M.P.”'(Chiel 1940). Box office for the film was indeed remarkable in Australia and the film also gained popular acclaim in Britain, where it was screened more than 1400 times before mid-1941 (Pike 1980:45).

The Rudd family texts are unique in Australian cultural history for the extent to which they have been adapted, and the degree of their popularity in a variety of media over time. Authors, producers, directors and publicists of these texts engendered a market defined by its recognition of Australian cultural commonplaces. In this respect the Rudd characters have been instrumental in the creation and characterization of a specifically 'Australian' audience that can be defined in relation to a set of national symbols. Dad Rudd, M.P., in particular, illustrates the way in which such national symbols can be a product of market imperatives, overseas influences and chance. 
Dad Rudd and his family first appeared in short stories by 'Steele Rudd' (Arthur Hoey Davis) in nationalist Sydney journal The Bulletin in 1895. These were bleakly comic sketches of life on a small, unprofitable and disaster-prone selection. The Rudds came to national prominence with the publication of On Our Selection! (1899), in which Davis's stories were collected, organized according to a narrative of poverty to prosperity, and provided with a bombastic dedication declaring 'Good Old Dad' to be the inheritor of the qualities of the 'Pioneers...who gave our country birth’ (Rudd 1992). This dedication was important in first framing Dad Rudd in particular as a nostalgic figure representative of a certain view of Australia's history which emphasised rural settlement and ignored both indigenous and convict history. Along with the structure of the collection, the dedication owed much to Bulletin editors J.F.Archibald and A.G.Stephens. These editors' expectations as to what would appeal to Bulletin readers had a lasting impact on Davis's writing (Fotheringham 1995:84).

On Our Selection! was enormously successful, prompting the Bulletin (and later A.C. Rowlandson's Bookstall Publishing Company) to publish at least eight further volumes of Steele Rudd stories. The subsequent volumes follow the Rudd family through vastly improving fortunes. The drought breaks, they move to a bigger and better selection and, by 1904, Dad is elected to Parliament. Dad in Politics (1908) is a significant departure in tone from the earlier stories. It contains pointed and topical political satire and presents the Queensland Parliament as inhabited by duplicitous, infantile rabblerousers with no understanding of those on the land. In some respects Dad in Politics is the model text for 
Dad Rudd, M.P., although as we will see, Davis and Hall approach the political narrative quite differently.

On Our Selection! (1899) has been regarded by many literary critics, particularly those working in the 1930s through to the 1960s, as one of the foundational, authentic nationalist Australian texts, alongside the work of Henry Lawson and A.B. 'Banjo' Paterson. Hall's films based on the Rudd family, along with other adaptations, have been derided by such critics for transforming Davis’s realist stories into generic, slapstick, bourgeois or populist texts. Brian Elliott, for example, argued that in the adaptations for stage and film, 'the Rudd family, instead of remaining splendidly at the level of the genuinely comic, descended to become a set of vulgar clowns designed to appeal only to the jejune tastes of the metropolitan mob’ (Elliott 1947:183). For Dorothy Green, as the Rudds become more prosperous, 'Dad ceases to be Davis's creation and becomes the creation of his audience' (Green 1980:35). Popularity therefore concerned these critics when it incorporated diverse 'metropolitan' audiences for theatre, film and radio contrasting the implicitly rural, relatively homogenous audience of the Bulletin and its book publications. In 1940, however, Hall asserted a continuum between the idealised rural audience of the 1890s and his contemporary audience, pointing out that 'at least 70 p.c. of the revenue from Dad and Dave pictures comes from the country' (Hall 1940).

Dad Rudd’s audience first became publicly visible in 1912, when the character appeared in a stage play produced by the Bert Bailey Company. The play drew an estimated audience of one million people between 1912 and 1916 in Australia and New Zealand 
(Fotheringham 1994:81). Adaptation for stage melodrama, carried out by Davis and Beaumont Smith, and then Smith and Bailey (Fotheringham 1994) required significant alterations to Davis's plot and characters, and much of the added conflict is structured by Dad's involvement in politics to defeat the play's villain. As Margaret Williams points out, On Our Selection (1912) was one in a long line of comedies which Australianized the American 'backblocks’ genre with great success (Williams 1983). Several critics deplored the use of melodramatic effects and plot devices in the play. Raymond Longford was among them, and his silent film, On Our Selection (Longford, 1920), actively worked against the 'backblocks' trend in which Bailey made his name, as well as the body of films that had been made by Beaumont Smith, Kate Howarde and others featuring the Hayseeds, the Waybacks and other Rudd-family look-alikes on the screen from 1917.

Ken G. Hall had no such scruples. His film version of On Our Selection (1932) closely followed the 1912 stage play, to the point of using many of the same actors, and grossed more than \$120,000 (Yates 2001). Hall’s timing enabled contemporary audiences to identify their own household struggles during the Depression with On Our Selection's stories of humour in the face of poverty and hardship, and of hard work leading to eventual prosperity. On Our Selection was the first film made by Cinesound and by Ken G. Hall, whose experience to that point had been primarily in film publicity and theatre management (Pike 1984: 65). Cinesound's subsequent focus on producing films primarily for the domestic market was informed by Hall's growing reputation as a 'showman' with an accurate eye for what would appeal to Australian audiences, 
particularly when it came to adaptations or Australianised versions of prior successes (Shirley 1983:129). Grandad Rudd (Hall, 1935), Dad and Dave Come to Town (Hall, 1938), and Dad Rudd, M.P. (Hall, 1940), Hall's three subsequent Rudd family films, aggressively modernised the characters, placing them in contemporary, urban settings which would have been familiar to Australian cinema audiences, both in terms of their own lives and of the films they went to see.

Dad Rudd, M.P. places the Rudd family in a contemporary, middle-class setting, from which position Dad enters politics in order to protect the interests of the small farmer against the scheming of a villain, Henry Webster. As in the earlier films and the stage play, the villain's son has romantic designs on Dad Rudd's daughter. Here, however, instead of being a proto-villain, Jim Webster is a proto-hero, defying his father in the end to support Dad Rudd's political contest and win his own romantic one. Dad enters politics to prevent Webster from getting in the way of plans to extend the height of a dam to help the small farmers of the area. The drama of the film is driven by the question of whether he will be able to beat Webster at the election, as Webster with his money and connections pulls a variety of crooked tricks to prevent Rudd from speaking to the people. Further suspense is created when, in accordance with Dad's prognostications, the dam bursts, destroying the bridge, and the vast majority of eligible voters are trapped on the wrong side of a raging river. Fortunately Jim Webster is an engineer, and speedily rigs up a remarkably sturdy flying fox, ferrying the electors to the voting booth just in time for them to vote Dad Rudd to victory. The climax to the film is Dad's maiden 
speech, a stirring five-minute invective in which he positions himself as representative of the 'plain people', contemporary inheritors of the values of the 'pioneers.'

While in many respects this film is remarkably different from Davis' stories and many of the later adaptations, Dad Rudd, M.P. incorporates previous Rudd family characteristics and narratives alongside models provided by contemporary American film. Bert Bailey as Dad and Fred MacDonald as Dave provide continuity between the 1912 stage play and all of Hall's films. The relationship between gruff Dad and goofy Dave - a London critic likened MacDonald’s performance to ‘congenital idiocy’ (Anon. 1920) - and between stubborn Dad and level-headed Mum are also relatively consistent throughout the adaptations.

From 1895 to 1952 the Rudd family formed part of what was essentially a serial narrative across various media and genres, with the same set of characters subject to various stories and settings. Dad Rudd, M.P. encourages this reading by opening in the family's kitchen, establishing within the first five minutes that Mum is still level-headed, Dad is still gruff and stubborn, and Dave is still goofy. The opening scene squeezes in as many symbols of modernity as possible: Dave is installing a new gas oven, Mum and the girls sit around a modern-looking kitchen, with Formica cupboards and table-tops, discussing Dad's new car. Within the first five minutes two comic set-ups play on the humour of Dad's stubborn attachment to the 'good old times': he mistakenly brings home laughing-gas instead of gas for the stove, and he brings it in his new car, which turns out to be the horse-dawn fire engine that the local fire department were selling to make way for their 
new automobile engine. Dad still carries an affectionate, Luddite connection to the past while his family are happily embracing all the gizmos modern life has to offer.

Andrew Pike writes somewhat despairingly of the shift in Dad Rudd's character between Hall's first and fourth film on the Rudd family: 'in the short space of eight years Dad and Dave were transformed by Hall into figures, not from the pioneering past, but from the urban middle-class present' (Pike 1984:67-68). While this is certainly the case, Hall was not the first to place the Rudd family in an explicitly modern setting. The radio serial, Dad and Dave from Snake Gully, which is discussed in further detail below, had been situating the Rudd family in the present since 1937. The radio serial and Hall's films, running concurrently, entrenched the reading of the Rudds as representing the conflation of Australian traditions with contemporary Australian life, as well as their role in a larger, serial, narrative. It is important to note that Dad has already become something of a middle-class figure in Davis’s Our New Selection! (1903), Sandy’s Selection (1906) and Dad in Politics (1908), and although Dad is perfectly successful in the 'urban, middleclass present' of the film, in it he still represents both the pioneering past and the ethos of the small farmer. Similarly the tropes that became most transferable between adaptations - the lines which were adapted and repeated between the stories, play and films - were those emphasising the ability to start with nothing and become prosperous through sheer virtue of hard work.

In Dad in Politics (1908) Dad rails in Parliament against the idea of assisting people to settle on the land, haranguing his listeners about his family, who 
worked - worked night an' day, worked in the house, and in the yard, and in the paddicks, and on the drays, and beside the stacks. They weren't afraid of gettin' sunburnt. They had courage. They had hearts! (A burst of applause.) And many a time they went without a bit o’ meat.' (More applause.) (Rudd 1984: 37).

This speech is duplicated, in truncated form, in the theatre adaptation of On Our Selection. Here, however, Dad makes explicit that his experiences are representative of the broader, contemporary, community: 'They 'ad courage, they 'ad 'earts, that's 'ow my family faced the land. And there is 'undreds of families doin' the same this very day' (Bailey 1984:133). It is this slippage between Dad Rudd as exemplar of social mobility and as epitome of the Australian working man that enables him, in the later films, to continue to represent workers once he himself is no longer struggling.

In Dad in Politics (1908), On Our Selection (1912) and Dad Rudd, M.P. (1940), dramatic emphasis is placed on Dad's speeches, wherein he confounds expectations placed upon him and makes his most trenchant defence of his constituents as Australian 'battlers'. When Bailey, as Dad, rises to give his stirring maiden speech at the conclusion of Dad Rudd, M.P., much of his audience would have been reminded of the famous speech, featured in both the 1912 play and 1932 film, in which Dad faces the wealthy villain and tells him that regardless of the hardship he might face, he can do 'Wot the men of this country with health, strength and determination are always doin'. I can start again' (Bailey 1984:95). In Dad Rudd M.P. attitudes this earlier speech assigned exclusively to 
bush pioneers (and emphatically not the wealthy developer to whom it is addressed) are more broadly distributed to middle-class urban audiences: Dad's constituents and those sitting in the cinema auditorium.

Dad's maiden speech in Dad in Politics is an angry, blustering comic piece punctuated with interjections and general rowdiness. Dad Rudd M.P. strikes a much graver note. Bailey stands, looking around seriously at his fellow politicians and his rapt audience in the gallery. When he speaks it is to define his constituents in such a way as to place them at the moral heart of the nation, and as inheritors of the virtues, values and experiences of 'the pioneers'. The speech yokes direct quotes from the earlier texts into a description of the contemporary Australian citizen. Here, the contemporary farmers are conflated with a description of the pioneers which is taken word-for-word from A.G.Stephens' dedication to On Our Selection! (1899): [clarify which source is being quoted: perhaps also give the dedication to show where it is cited]

Some members have spoken about the cost of increasing the height of this dam another $50 \mathrm{ft}$. I want them to think of the people who made this work necessary. The pioneers who crossed the plains in their dragging, creaking drays, who strove through the silence of the bush and made it ours.

Many of their names are not engraved on tablet or tombstone, and they have no place in the history of our country so far as it is yet written. But they are the men 
and women that gave our country birth. They had faith, a magnificent faith which is our heritage.

'The pioneers', here and in Stephens' dedication, is a purposefully vague term alluding to settlers, explorers and any others defined by their claiming of the bush for settler Australia as well as their lack of recognition in public life. This latter emphasis allows for the slide between the pioneers and a general, idealised picture of the ordinary Australian:

the plain people who have fought and won and lost and always carried on... it is the plain people who are the heart and soul and backbone of our country.

The term 'plain people' does not appear in any earlier adaptation, nor in the original stories. In the film it acts to enable an ambiguous picture of the ordinary contemporary Australian to be imaginatively linked to the nostalgic narratives of Australian settler history that have long been referred to by Rudd family texts. The contemporary context is emphasized when Dad, in a rather abrupt shift, begins to speak about a question 'that is filling the heart and mind of every man and woman in this commonwealth today [...] As I stand here, the drums of war are sounding at every capital in the world.' As a musical medley including 'Land of Hope and Glory' swells in the background, Dad continues in a vein of what is, for him, absolutely unprecedented Empire patriotism: 'as I stand here, our young men have marched again, to take their place by the side of their blood brothers of the Empire.' The struggles of the pioneers are equated to the sacrifices of 'our young 
men' in wartime. In his autobiography Hall notes the expediency of this sudden flowering of war and Empire in Dad's speech: 'because of the outbreak of war, we gave the speech a new patriotic twist half way through' (Hall 1977:157). The speech becomes a wartime call for unity and sacrifice:

In the hearts of our men and women lies a passion for justice. ... A jealous regard for our rights and privileges, the establishment of the equality of individuals, whether they belong to majorities or minorities. For they are the rights of man. [thumps fist on table]

I am an old man now. And once again I watch our youth in that new but age-old struggle to preserve that freedom which is our heritage. We must not fail. In the name of that spirit which is their inheritance, a spirit which is yours and mine, and which will go down to their children's children. In the name of these men, who are risking their lives, and all the future holds for them, I ask you to put aside bitterness and enmity, to let the blood of true nationalism run fast in your veins, and by unity and strength of purpose act so wisely that in peace may come prosperity, honour and great nationhood! To this our land.

The music swells as the film ends with a montage of Dad Rudd's disembodied head, squinting proudly at the camera while superimposed upon a gently waving Australian flag, itself superimposed upon an idyllic outback landscape. The montage evokes a less than subtle equation: Dad Rudd $=$ Australia $=$ the bush. As he moves his head left and 
right, his gaze directed at the camera, the audience are invited to see themselves as part of the vista he proudly claims as his own: as the fourth factor in the equation.

This pictorial montage draws attention to the speech itself as a verbal montage of symbols of settler history, agrarian populism, nationalism, nostalgia, anti-fascism and empire loyalty. The sheer representative force of the image of Dad Rudd's head is enabled by the 40 years of stories, plays, films, advertisements and public discussion that had acted to cement Dad Rudd as symbolic of a particular image of Australia's history, centred upon hard work, rural life and social mobility which itself came to stand in for Australia as a whole.

As tempting as it is to become swept up in such uplifting national fervour, the image of Australia that Dad Rudd epitomized in 1940 was heavily influenced by Australian audiences’ taste for and consumption of a different kind of empire: American popular culture. I'd now like to turn to the question of how Dad Rudd changed in his 1940 incarnation, and to speculate as to why these changes took place. As noted above, Dad in Politics (1908) is in some respects the model text for Dad Rudd, M.P. but the latter takes up Rudd's narrative with a much more positive attitude to politics. In each, Dad's entrance to politics is preceded by the death of the local member. Dad in Politics opens:

Smith, the member for our district, died one day, and we forgot all about him the next. Not that a politician is ever remembered much after he dies, but Smith had 
been a blind, bigoted, old Tory, and was better dead. Politicians are mostly better dead, so far as other people and their country are concerned. (Rudd 1984 1)

In Dad Rudd, M.P., the men announce to Dad that Bill Madden, the member for the district, has died, and they all stand, hats in hands, commiserating: 'Poor old Bill, the best member this district's ever had.' Parliament is represented in each, respectively, as a bear pit and as the epitome of respectability. As Dad becomes more and more of an everyman who can function in different social spheres, in Dad Rudd, M.P. he becomes less a character of grievance and more a battler against a very specific wrong, Webster's support of a lower dam. As in the stage play, he comes to represent a moral constituency that draws its righteousness from a nationalist and sentimentalised idea of Australia's history. Dad Rudd is still standing up for the interests of the small farmers of the 'district', but is doing so out of a more elevated sense of the good of the whole community. Dad's maiden speech in Dad Rudd, M.P. is punctuated, not by interjections, but by long pans of fellow MPs and visitors in the gallery, united in their approval of Dad's depiction of the 'plain' people and what they mean to the country and the Empire.

The influence of American film had much to do with the dramatic shift in the representation of politics across these texts. As Pike and others have pointed out, Hall's films owe much to Frank Capra's comedies. It’s difficult not to see Dad and Dave Come to Town (1938) as indebted to Capra's Mr Deeds Goes to Town (1936), and likewise Dad Rudd, M.P. (1940) has much in common with Capra's Mr Smith Goes to Washington (1939). The latter film was released in Australia earlier in the same year as Dad Rudd, 
M.P., was successful at the box office and received high praise in the Australian press (Anon. 1940a). The extent of the similarities between the two films suggest that Hall probably saw the film in its earlier American or British release, or at the very least was exposed to some detailed pre-release marketing material. [was Hall in USA UK? If so say when] Each sets up a fish-out-of-water scenario wherein a politically naïve, 'ordinary' man enters the world of politics. In each, the political battle centres upon the building of a dam. Both narratives are resolved by a virtuoso speech given by the protagonist.

It is also tempting to speculate that the montage which closes Dad Rudd, M.P. is an homage to or even a spoof of a similarly patriotic montage which takes place in $\mathrm{Mr}$ Smith, when Smith is visiting the political monuments in Washington. In this case the montage features the Supreme Court Building, the White House, the Liberty Bell and Constitution Avenue, culminating in Mr Smith’s awestruck apprehension of the Lincoln Memorial, where he reads parts of the Gettysburg Address aloud. This montage, as with both speech and montage in Hall's film, is accompanied by a medley of patriotic songs: the medley created by Dimitri Tiomkin for Capra’s film includes 'Yankee Doodle,' 'My Country 'Tis of Thee,' 'Red River Valley,' and 'When Johnny Comes Marching Home.' The patriotism of Mr Smith is focused on the nation's political history and icons to a degree that illuminates the lack of such a focus in popular Australian nationalism, which, as evidenced by Dad Rudd, has tended to focus on individualist characters and rural iconography. 
The most incongruous sections of Dad Rudd's maiden speech in Dad Rudd, M.P., in which he speaks about the equality of individuals and the rights of man, certainly echo the moralistic, rights-based language of Mr Smith’s grand filibuster. It is likely that Hall was influenced by the optimism that characterizes many American narratives about politics and by the political inflection of American nationalism in creating Dad Rudd, M.P., and that this more positive view of politics in its relationship to nationhood would have resonated with a wartime Australian audience.

Hall's decision to place the Rudd family in a contemporary setting was also in all likelihood influenced by the popularity of Dad and Dave from Snake Gully, a radio serial based loosely on the Rudd family which narrowly avoided copyright infringement by never mentioning the surnames of any of its characters. Snake Gully ran for more than two thousand episodes from 1937 to 1952, and was often accompanied by a Stan Cross comic strip in the popular magazine, Smith's Weekly. The radio serial was modelled on the American program Amos n' Andy and was initially devised by an advertising company in an attempt to overcome Australian resistance to the American habit of chewing gum. Shop hoardings across the country bore the slogan, 'Wrigley’s Chewing Gum: As Australian as Dad and Dave’ (Fotheringham 1995:335). This marketing strategy presumed that Australian characters in an American-style format would be appealing enough to an Australian audience to persuade them that an American habit is actually Australian. Clearly nationalism was an effective tool for selling cultural and other kinds of products, which could also sit unproblematically alongside the appropriation of American cultural forms 
The success of Hall's Rudd family films suggests the readiness with which Australian audiences approached American cultural forms, particularly when they were inhabited by well-known and recognized Australian-style characters. A review of Dad Rudd, M.P. in Smith's Weekly describes the film as 'a slice of Australian backblock life as discovered by Steele Rudd long years ago; and one must congratulate Cinesound for having copied the American model so cleverly...The whole effect is generally hopeful for the future of Australian films' (Anon. 1940b). The chewing gum strategy shows that the most immediately recognized meaning of the Rudd family (or at least Dad and Dave), was simply 'as Australian.' It also suggests that the 'American model' contributed in no small way to the development of characters and narratives that continued to be used in public discourse to define what 'Australian’ meant.

The meanings incumbent upon Dad Rudd were not only created and circulated in the Rudd family texts, but also in how they were framed in marketing strategies. People who may not have seen Dad Rudd, M.P. were still likely to have been exposed to the messages of its extensive, five-month long marketing campaign. In the introduction to his review of the film, Brisbane Courier Mail film reporter writes, 'In the last few months I have written hundreds of words on the subject of Dad Rudd, M.P., the latest Australianmade film' (Pana 1940). Cinesound, Greater Union Theatres and Associated-B.E.F. released copious public statements to the press which received broad coverage in the metropolitan broadsheets. Two months before the release of the film, a major campaign centred on gathering signatures for Bert Bailey’s $70^{\text {th }}$ birthday was launched. Bailey and 
Fred MacDonald made numerous public appearances and radio interviews in the lead-up to the film's release. The film was tied-in with dance organizers to promote 'Dad Rudd Revels.' Five thousand posters were put up around Sydney. A 'Dad and Dave' cartoon strip was placed in the Daily News over the period of the campaign, recorded talks were played on radio stations in several states, and a running commentary on celebrities at the premiere was broadcast live on 2UE. According to Film Weekly:

A truck was bannered with Dad Rudd heads and other advertising material, and was equipped with an amplifier and special record discs. The truck pulled up on street corners and collected crowds, with preliminary announcements, and then the amplifier sent forth praise of the Cinesound attraction...It was out for a full week and interested thousands of people...Another novel idea was put into operation whereby two men dressed as artisans carried around a banner on a frame measuring 12ft. x 4ft (Anon. 1940c).

Even people who were not movie-goers were likely to have encountered Dad Rudd on the streets, in the papers or on the radio if they lived in an Australian capital city in early 1940. The extent of this marketing campaign shows the purposefulness with which those promoting the film set out to create an audience for it. A brief survey of the messages of the campaign confirm that it set out to create a market who defined themselves as Australian. 
Statements released by Associated-B.E.F to promote Dad Rudd, M.P. drew on nationalist sentiment in order to emphasize the broadness of its appeal: 'It's a grand Australian story that every Australian will thoroughly enjoy' (Anon. 1940d). Film Weekly described it as a 'modern, typically Australian comedy, rich with true Australian ideals and sentiment' (Anon. 1940d).

The appeals to nationalism in the publicity campaign for Dad Rudd, M.P. took advantage of the particular nature of wartime patriotism, linking Australian national sentiment to love of Empire and utilising the sense of seriousness that attached to wartime talk of what is important for national wellbeing and survival. According to Greater Union chairman Norman B. Rydge, the film 'touches, in a moment of Empire gravity, a note of nationalism that is inspiring. Australia will rock with mirth at "Dad Rudd, M.P.”; but his courage and sublime faith in his country will give courage to his countrymen to face the problems that beset them' (Anon. 1940e). The Government overdraft received for the film provided legitimation and reason to emphasize the 'national importance' of the film in its marketing. A paragraph in the Brisbane Courier prior to the film's release admires the fact that 'A note of national importance is struck by the introduction of the problem of water conservation for the man on the land. This is the inspiration for Dad's political aspirations' (Anon. 1940f). Likewise, B.E.F. national manager points out that the film centres ‘around a great national necessity - water conservation’ (Anon. 1940d). The term 'national importance' can be used with such gravity in this promotional material because it is produced in the context of a nation at war. As asserted by Hall in his comments in Film Weekly, Dad Rudd was already assumed to be an 'Australian tradition'. The 
wartime context and marketing of the film elevated this popular tradition to one of political importance.

Much of the promotional material for Dad Rudd, M.P. focussed on an image of Bert Bailey’s head (see Figure 1 below).

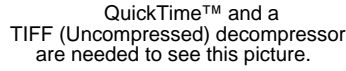

Figure 1. Lobby card for Dad Rudd, M.P. Copyright Cinesound Movietone productions.

By 1940, Bert Bailey and Dad Rudd had become virtually indistinguishable in the eyes of the Australian public. If you were to scan the lobby card (Figure 1) quickly, you would come away with the words 'Bailey' and 'Dad Rudd' foremost in your mind, the two equated by font size and their proximity to the benign visage of the man himself. Film Weekly, listing the 'selling angles' for the film, first mentioned 'The evergreen character 
of Dad Rudd, as presented by Bert Bailey’ (Anon. 1940g: 27). By the time Bailey first played Rudd on the stage, he was already widely-known by audiences from his work in other Australian 'backblocks' stage comedies and so brought to the public imagining of Dad all of the nostalgia and familiarity invoked in those plays. Regardless of any changes made to the character, the fact of Bailey playing the role of Dad Rudd ensured that the character would be read as congruent with that in the earlier films and the play. The campaign to gather a million signatures to present to Bailey upon his $70^{\text {th }}$ birthday happily situated in the same year as the film's release - was promoted 'as part of a nation-wide tribute to "Dad," by which title Bert Bailey is know (sic) from one end of Australia to the other' (Anon. 1940h). Bailey is conflated with Dad as recognized by a distinctly local Australian audience.

The other key image in the promotional material for the film was the voting card. Film Weekly describes the catchline for selling the film to be 'Australia's Prime Minister of Mirth Gets First Vote for Fun’ (Anon. 1940g). Posters, advertisements and lobby cards featured the slogan, 'give him your first vote for fun!' Advertising Bailey/Dad (however cheekily) as a real electoral candidate implies the conflation of audience and constituency. Bailey, as Dad, represents not only the collective identity of the Australian public, but also their collective tastes. Dad Rudd's constituents, the 'plain people,' are really the 'ordinary' Australians who flock to see Bert Bailey's portrayal of him in the cinema. A similar rhetoric was at work in the promotion of $\mathrm{Mr}$ Smith Goes to Washington, which used the slogan: 'The people's choice - put Smith in Washington for 
life!' (Smoodin 1996:11). Smoodin suggests that the blurring of real and fictional political process in the advertising for the film

worked to create a response to the very act of going to the movies. Through advertising, the theatre came to be equated with yet another "private" space where people could feel themselves to be both part of a greater community and also alone-the voting booth (Smoodin 1996:11).

Here, popular texts about politics acted to create a sense amongst film-goers of being part of a public grouping which was at once audience and constituency. The act of going to see a film could become, like the act of voting, one that defined you as part of a national community.

Dad Rudd's maiden speech was shot in the New South Wales Parliament House; the representation of elections and the political sphere within Dad Rudd, M.P. and in its marketing, along with the explicit contemporariness of the film, invites some conflation of the fictional and the real on the part of its audiences. Dad Rudd was certainly read as a fictional character, but the position he offered his constituents, to themselves be representative of the 'plain' or 'ordinary' Australian people, in could well have been taken up by audiences as part of how they defined themselves in relation to the rest of the Australian public and the political process. 
The question as to how Dad Rudd, M.P. was read - and produced - as representative of a real Australian public is brought into focus by the public debate that surrounded the film. One New South Wales politician, E.M. Horsington, was so concerned about the accuracy of the film's portrayal of rural Australians that he asked a series of questions about its receipt of the Government overdraft in Parliament, including:

(d) does the guarantee cover the "Dad and Dave" type of picture, which may misrepresent country life in New South Wales? (3) Will he take steps to ensure that any picture purporting to represent country life in Australia does to some extent represent the true conditions of country life in New South Wales? (NSW Hansard, 30 April 1940).

The Colonial Secretary quite sensibly responded, 'The films to be produced are of a fictional, not documentary, type.' The two were often confused when it came to Steele Rudd. Horsington's comments show that Australian audiences came to Dad Rudd, M.P. with a well-established set of expectations as to the "'Dad and Dave" type of picture', and that such expectations included their purportedly realistic representation of Australian life. In Horsington's outrage, Hall was reaping the effects of forty years worth of public assertion as to the representative nature of the Rudd family texts.

Following Horsington's comments, trade paper Film Weekly, with Ken Hall as its vanguard, fought back. The Weekly ran a front-page story headlined 'UNFOUNDED ATTACK ON DAD-AND-DAVE COMEDIES' which in itself constituted an effective 
piece of advance publicity for the film. In his response, Hall deflects Horsington's charges of representational inaccuracy by repositioning them as an attack by the educated elite on the tastes of ordinary Australians. He claims the popularity of the Rudd family stories as proof of their authentic Australianness at the same time as emphasising their fictional (and thus not literally representative) nature. In effect, he is arguing that they Rudd family are representative of the tastes of the Australian public, but not of the Australian public itself, and that the Australian public are themselves smart enough to know the difference.

Hall's defence of Dad Rudd. M.P. became a defence and description of his audience, which was explicitly defined in national terms. Dad and Dave, he claimed, were 'national characters' and 'part of the folklore of our country':

Mr. Horsington may urge the Government 'not to approve Dad and Dave pictures'; but HE CAN'T STOP DAD AND DAVE! Created nearly 40 years ago, these characters have stood the test of time, and they will forever remain with us, despite the gibes of some politicians, and what the few intellectual snobs who crop up from time to time may say to the contrary. They are a tradition!

Hall implies a ‘tradition' of Australian audiences who have all recognized Dad and Dave; in this sense, he posits Dad and Dave as proof of the enduring tastes and beliefs of the Australian public. Placing authority squarely in the hands of the punters, Hall produces as evidence: 
the popularity of the Dad-Dave stories in book form; next, the huge money they made over a long course of years as stage plays; and, finally, the immensely greater fortunes they have netted through the screen... Does this mean that Mr. Horsington - and the comparative few who think with him - are right, and 98 p.c. of Australian entertainment-seekers are half-wits? (Hall 1940).

Hall defines his audience, 'Australian entertainment-seekers,' in opposition to the ‘inferiority complexed-Australians’ and 'intellectual snobs’ who criticise the Rudd family narratives. He uses Dad and Dave as proof of the existence of a mass audience who are themselves authentically and distinctively Australian. The assertion of a popular constituency, a 'mainstream', defined as having access to recognisably Australian characteristics in contrast to an educated 'elite' is essentially a populist strategy which has been equally effective in creating both markets for cultural productions and political constituencies in Australia. Hall, in describing Dad's constituency as 'the plain people', used almost precisely the same turn of phrase as did Robert Menzies, who in his 19** radio address was appealing to the same audience: both the plain and the forgotten people are described as ‘the backbone of the country’ (Hall 1940, Menzies **?).

Rhetorical reliance on the idea of the mainstream, the ordinary, the middle class, has long been a feature of the public discourse of Liberal Party politicians. This 'mainstream' has been described, by Labor and Liberal respectively, in terms of hard work and social mobility. An idea encompassing both, 'the battler', has come to stand in for the 
constituency that must be won in order for a party to gain power in Australia; since his election in 1996, 'Howard's Battlers' has become a common trope in journalism and political speeches to exemplify John Howard's appeal to a lower-middle class constituency that was previously loyal to the ALP. In recent years the term 'aspirational' has become increasingly common to try to describe a population who, in the main part, are no longer struggling. The Rudd family texts were instrumental not only in the articulation of a distinctly Australian mass audience but also in the characterisation of this public in terms of a certain view of Australian history. Since the post-WWII period, there has been a mismatch between the images used to describe Australian identity (rural, struggling, working-class) and the reality of Australian demographics. The Dad Rudd texts were instrumental in articulating the continuity between the battler and the aspirational as tropes that could structure Australians’ collective identity.

From the dedication to On Our Selection!, framing 'Good Old Dad's inheritor of the spirit of the pioneers, to the assertion that Wrigley's is 'as Australian as Dad and Dave', Dad Rudd has been part of strategies to appeal to a wide but distinctly Australian audience.

The ways in which people have continued to see themselves as part of an Australian public has been influenced by popular cultural productions such as the Rudd characters, which themselves were strongly influenced by the popular cultural productions from elsewhere in the world. The success with which these texts attracted an audience who saw themselves as 'Australian entertainment-seekers' may well have created the ongoing 
attractiveness of nationalist tropes like the battler in building political constituency in Australia. In 1940, Dad Rudd, M.P. provided a way for people to become part of an audience that itself constituted a form of national community.

\section{References}

Anon. (1920), 'On Our Selection: Australian Play at the Lyric', Times, 25 August 1920.

- (1940a), 'Highly Successful Opening of Columbia's "Mr Smith Goes to Washington" at the Sydney State', Film Weekly, 25 January 1940.

— (1940b), 'Untitled Review', Smith's Weekly, 22 June 1940.

— (1940c), 'Launching "Dad Rudd, M.P.," At Syd Premiere', Film Weekly, 4 July 1940.

— (1940d), 'Cinesound's "Dad Rudd, M.P.," for simultaneous release in two Sydney theatres on June 14', Film Weekly, 9 May 1940.

- (1940e), "Trade Screenings to be Given in All States of the New Cinesound-Bert Bailey Comedy, "Dad Rudd, M.P."', Film Weekly, 6 June 1940.

— (1940f), 'Comedy and Politics', Courier Mail, 6 June 1940.

— (1940g), 'Untitled Review', Film Weekly, 20 June 1940.

— (1940h), 'Autograph Tribute to Bert Bailey', Film Weekly, 23 May 1940.

Bailey, B. (1984), On Our Selection: A Dramatisation of Steele Rudd's Books, Sydney: Currency Press.

Chiel, T. (1940), 'Untitled Review’, Australasian, 14 September 1940.

Elliott, B. (1947), Singing to the Cattle and Other Australian Essays, Melbourne: Georgian House.

Fotheringham, R. (1994), 'When the Devil Drives: the plays of Steele Rudd', Australasian Drama Studies, 25, pp. 81-98.

- (1995), In Search of Steele Rudd: Author of the classic Dad \& Dave stories, St Lucia: University of Queensland Press.

Green, D. (1980), 'No Laughing Matter', Bulletin Literary Supplement, 30 September 1980, pp. 28-35.

Hall, K. G. (1940), 'The attacks by E.M. Horsington on the Dad-Dave type of pictures', Film Weekly, 18 April 1940.

- (1977), Directed by Ken G. Hall: Autobiography of an Australian Filmmaker, Melbourne: Lansdowne Press.

Pana, T. (1940), 'Australian Film Takes a Bow', Courier-Mail, 15 June 1940.

Pike, A. (1984), 'Dad and Dave in the cinema', in B. Bailey, On Our Selection: A Dramatisation of Steele Rudd's Books, Sydney: Currency Press, pp. 62-69.

- and Cooper, R. (1980), Australian Film 1900-1977: A guide to feature film production, Melbourne: Oxford University Press.

Rudd, S. (1984), Dad in Politics and other stories, St Lucia: University of Queensland Press.

— (1992), On Our Selection!, Pymble, NSW: Angus \& Robertson. 
Shirley, G. and Adams, B. (1983), Australian Cinema: the first eighty years, Sydney: Angus \& Robertson.

Smoodin, E. (1996), "Compulsory" Viewing for Every Citizen: "Mr. Smith" and the Rhetoric of Reception', Cinema Journal, 35, pp. 3-23.

Williams, M. (1983), Australia on the Popular Stage 1829-1929: an historical entertainment in six acts, Melbourne: Oxford University Press.

Yates, S. (2001), 'The greatest Dad', Daily Telegraph, 20 January 2001. 